\title{
The Crisis of Social Democracy and the Search for a Transnational Response
}

Derya Kömürcü, PhD.

\author{
Department of Political Science and International Relations, Yıldız Technical University
} Email: deryakomurcu@gmail.com

\section{Doi:10.5901/ajis.2014.v3n1p173}

\begin{abstract}
This article aims to analyze the crisis of social democracy with a specific focus on the opportunities that have appeared at the transnational level and to offer a critical consideration of the social democratic responses to the challenge of globalization The political integration of the European Union offered a new opportunity of responding to the challenge of globalization for the European social democracy at the transnational level. In this context, assessing the extent to which the Party of European Socialists (PES) could become an influential transnational party is crucial to envisage the future of a globalist social democracy. The article demonstrates that social democratic politics at the PES level is about contending individual member parties rather than pursuing a social democratic EU-oriented strategy and the PES' main function is to operate as a coordinating mechanism and discussion platform for national political parties.
\end{abstract}

Keywords: social democracy; crisis; the Party of European Socialists; transnational social democracy; the European Union.

\section{Introduction}

Arguments on the crisis of social democracy have been prevalent for some years. In the early 2000s, the emergence of the Third Way politics as a renewed form of social democracy and its pro-market stance deepened the discussion on what social democracy is and what kind of future is waiting for centre-left politics in a global era.

Although the debate on the future of European social democracy has been shaped by contributions focusing on the characteristics of centre-left politics in various European countries, a new tendency of focusing on 'globalist' social democracy has come into view during the last two decades (Martell, 2001). It has been argued that the political integration of the European Union could be the response of 'new' social democracy to the new conditions of the neoliberal age. In this context, analyzing European social democracy at the transnational level and assessing the extent to which the Party of European Socialists (PES) can become an influential transnational party is crucial to the broader task of envisaging the future of globalist social democracy.

In the light of these concerns, the purpose of this article is to offer a critical consideration of the social democratic responses to the challenge of globalization and to point out the opportunities for an alternative model for European social democracy. First, the pressures of globalization on centre-left parties and the historical evolution of social democracy will be elaborated, and then, different social democratic approaches to the crisis will be introduced. Finally, the Party of European Socialists will be analyzed as an attempt to challenge the imperatives of the global world at the transnational level.

\section{Pressures of Globalization on Social Democracy}

It is widely accepted that post-war social democracy, based on the idea of the welfare state and the Keynesian economic management has been in crisis due to globalization (Pierson, 2001, pp. 114-127). Social democratic governments' ability to achieve their traditional aims is undermined as national economies have become more and more dependent on the world economy, international trade and direct investment. As Sassoon (1996) mentions, the decline of nation-state and of social democracy are interlinked (p. 771).

However, a common belief in social democratic literature is that social democracy has been undermined not by globalization per se, but rather by ideas about globalization (see Vandenbroucke, 1998; Hay, 1999; Callinicos, 2001). On the contrary, some claim that "notwithstanding the theoretical controversies it provokes, globalization is a reality. And this reality, like every reality, has its own logic, produces results, and generates constraints. Once set in motion, globalization, real or perceived, has become part of the established economic order" (Moschonas, 2002, p. 264). And the so-called 
global economic order urges social democratic parties to reformulate their ideological and programmatic stances.

Post-war social democracy used to be a programme designed for national territories. As social democracy has come to adopt the liberal parliamentary system and as its primary concern has evolved towards capturing the governmental power through electoral process, the movement had become dependent on the capacities of the nationstate, which are now increasingly weakening (Habermas, 1999, p. 49).

Analysts of social democracy came to claim that in a global world, where interdependence is the basic aspect, traditional social democratic policies are inappropriate. The main assumption is that "the global freedom of capital demolishes the economic foundations of social democracy" (Gray, 1996, p. 26).

On the other hand, globalization can be interpreted in various ways having different political and socio-economic implications. For example, Vandenbroucke (1998) claims that although capitalist relations of production have spread rapidly across the world, a world economic system having actors that are completely interdependent, has not yet come into view (pp. 7-11). Social democrats argue that national governments have not yet lost their capacity to act as agents at the national level and that they can become influential at the global level (see Hay, 1999; Pierson, 2001).

It is true that national governments -especially the European ones- can still enjoy a range of options to preserve their capacity to be influential in policy areas such as employment and social welfare, but it should also be mentioned that "whatever social policies they choose, they must adapt to constraints imposed by deregulated markets - in particular global financial markets" (Habermas, 2001, p. 11). That is why the weakening power of the nation-state has made it crucial for social democratic parties to seek strategic cooperation at the European Union (EU) level. This has been reflected in the developments that took place within the party system of the EU during the last decade. For this reason, many observers claimed that the future of social democratic/socialist politics in Europe could be closely linked with the future of the PES (Lightfoot, 2005; Ladrech, 2000). However, the role attributed to the PES within European social democracy has been problematic due to the misconceived nature of the crisis and the characteristics of social democracy. Therefore, some clarifications on the nature of the crisis that European social democracy have been facing in the last 30 years, have to be made.

\section{Conceptualizing Social Democracy}

Works on the crisis of social democracy usually lack a concrete definition of the term. A general approach is to present the characteristics of post-war social democracy as the movement's universal tenets. These include "pervasive state involvement in social and economic life; state dominance over civil society; collectivism; Keynesian demand management, plus corporatism; confined role for markets: the mixed or social economy; full employment; strong egalitarianism; comprehensive welfare state, protecting citizens 'from cradle to grave'; linear modernization; low ecological consciousness; and internationalism" (Giddens, 1998, p. 7).

However, this is a mispresentation of the history of social democracy. By schematising social democracy as such, advocates of the Third Way ignore the categorical difference between the main objectives and the policies, i.e. they substitute the instruments for the aims. From its emergence as a moderate version of socialism till now, social democracy has had some fundamental ideological elements that have constituted its main objectives, yet the policies and the instruments to implement them have been transformed, reformulated, reinterpreted or abandoned. Keynesian economic management, corporative policies and welfare state do not explain the complexity of the social democratic tradition.

Social democracy has never had a fixed doctrine, but it has been "a political movement, as protean as the capitalist economy and society which has given rise to it. It is not a particular historical programme or regime or political party or interest group, or even an unchanging set of values. As a political movement its only fixed point is its constant search to build and sustain political majorities for reforms of social and economic institutions which counter justice and reduce inequality" (Gamble and Wright, 1999, p. 2).

In this context, Colin Hay (1999) places social democracy on a tripartite body composed of a commitment to redistribution, a commitment to democratic economic governance and a commitment to social protectionism (p. 57). This approach may be useful to understand the characteristics of post-war social democracy, but it lacks a historical perspective. Absence of a full account of the historical evolution of social democracy prevents us from understanding the underlying reason of the crisis of centre-left politics.

A historical perspective is essential, because the crisis of social democracy does not originate from its core, i.e. from its ideological and ethical values. The main problem of centre-left politics is embedded in the strategic turns that social democratic parties have made with regard to the social, economic and political transformations of their time. In the past decades, social democracy has failed to make the strategic turns that the global era imposed. 
Table 1 demonstrates the historical evolution of European social democracy in four different periods. Although there is a radical change between the first and second period concerning the main objective of social democratic movement, instruments to implement them evolve in a linear manner till the last period.

Table 1. Historical Evolution of Social Democracy in Europe

\begin{tabular}{|l|l|l|l|c|}
\hline \multicolumn{1}{|c|}{ Period } & \multicolumn{1}{c|}{ Basic Feature } & \multicolumn{1}{c|}{ Main Objective } & \multicolumn{1}{c|}{ Instrument } & Location \\
\hline Pre-war & Industrialization & Overthrow capitalism & Organised working-class & International / National \\
\hline Inter-war & Democratization & Mitigate the ills of capitalism & Parliamentary politics & National \\
\hline Post-war & $\begin{array}{l}\text { Development / } \\
\text { Wealth }\end{array}$ & $\begin{array}{l}\text { Redistribution of wealth and } \\
\text { Social protection }\end{array}$ & $\begin{array}{l}\text { Welfare state and Keynesian } \\
\text { economic management }\end{array}$ & National \\
\hline Global & Globalization & $\begin{array}{l}\text { Democratization of global } \\
\text { system }\end{array}$ & $\begin{array}{l}\text { Transnational party federations } \\
\text { and bodies of global governance }\end{array}$ & Supranational \\
\hline
\end{tabular}

In the pre-war period social democracy had working-class commitments and aimed to overthrow capitalism. However with the democratization of politics that consolidated in the inter-war period, social democracy transformed into a 'power oriented' political movement and eventually became nationalist, still having close ties with trade unions. Basic feature of the post-war period was economic welfare, which was combined with enlarging democratic and social rights. Social democratic parties were committed to redistribution of wealth, democratic economic governance and social protectionism.

Contemporary social democracy is in the process of breaking its historical continuity. The transformations that were brought about by the processes of industrialization, democratization and development/growth differed according to the national context, thus have been influential on the variations within the social democratic tradition. However, there is a paradigm shift between the first three periods and the global one. The basic feature of the first three periods all took place at the national level, but the basic feature of the fourth period is globalization, which basically takes place at the supranational level. Thus the nationalist paradigm of post-war social democracy is far from offering a solution to the contemporary crisis that social democrats have to face.

Even though Giddens and others claiming the death of 'classical social democracy' have detected the source of the problem at the right place, namely the process of globalization with its social, economic and political consequences, their definition of, and thus solution to the problem is inadequate. The problem does not lie on Keynesian economic management, welfare state or social democratic parties' conception of equality, redistribution and social inclusion, but takes its sources from the fact that "in the course of the evolution of socialism over the past one hundred years, its practical politics turned to social democracy in the modern nation-state. Substituting state for class, and nation for capitalism, the left maintained its transformative conception of politics"(Ladrech, 2000, p. 41). That is to say, internationalist, humanist, working class movement of nineteenth century socialism transformed into a nationalist, developmentalist, redistributive social democracy. In such conception of social democracy, the nation-state became the motor for progressive change of the capitalist society. As Ladrech (1999) mentions "one of the key changes in social democratic parties' development was acceptance of the liberal parliamentary state. From this point onwards, electoral mobilization played a key role in the attempt to gain governmental power and implement progressive policies" (p. 220).

Under the conditions of globalization, social democrats continued to search for a governmental power similar to that of the nation-state to implement their progressive policies, but there was no such power to be captured. This has been the basis of the crisis of social democracy and this has been the point where centre-left responses to globalization differ and unite.

\section{Social Democratic Responses to the Crisis}

There are three main responses to the challenge of globalization within the European social democracy:

1. National level centre-left politics that still emphasises the role of national governments in implementing social democratic policies;

2. Transnational level social democracy that basically aims to pursue some social democratic policies with coordinated action in the EU, and

3. The Third Way as a pro-market stance that argues for an adaptation of social democracy to the neoliberal rules of economic globalization while referring to some social democratic values of the post-war period.

This categorization can also be applied to 'the camps on Europe'. There have been 'defensive' and 'offensive' approaches to the political union of Europe within the European centre-left during the last decade. Within the 'defensive' 
approach there were 'Eurosceptics' and the Third Way which combined neoliberal, pro-market position with the concern of national sovereignty and saw the EU in terms of 'negative integration' whereas 'Eurofederalists', who fit into the 'offensive' approach, aimed a democratic, social, European federal state.

Habermas (1999) have distinguished three camps on the future of European integration. First category is 'Market Europeans' who are essentially neoliberals and happy with the current situation; second category is 'Eurosceptics' in which there are nationalists, 'old style' left as well as a defensive version of the Third Way which is basically in cooperation with 'Market Europeans' in their defence of the European status quo; and third category is 'Eurofederalists' who seek for a united federal Europe with a political constitution that will give legitimacy to the decision making procedure of the EU (pp. 56-57).

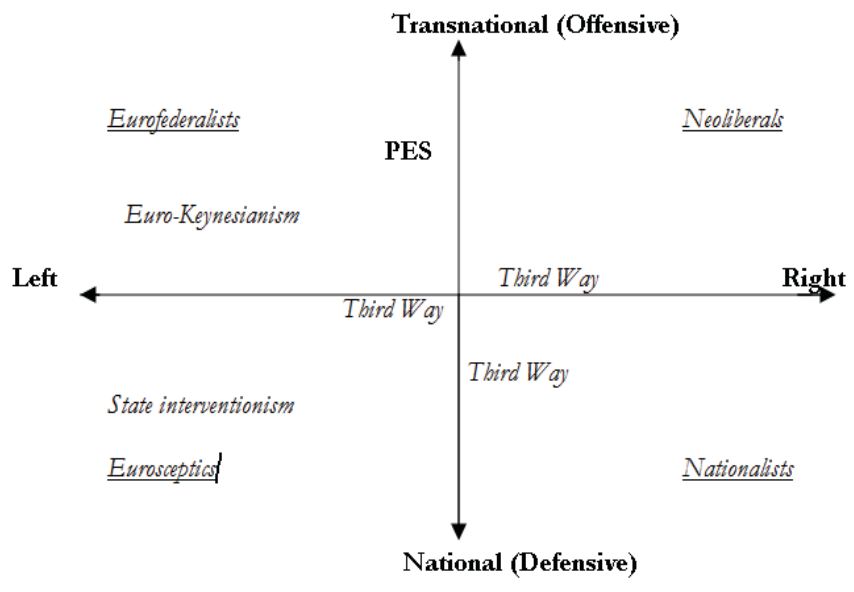

Figure 1. Camps on Europe and Centre-Left Positions

Besides the different camps on the European integration and the variety of social democratic responses to the new political atmosphere, Figure 1 aims to emphasize the fact that there is more than one Third Way. The Third Way is a political programme, which takes different shapes and can have different priorities according to the peculiarities of the context it is applied and thus, it is possible to talk about 'multiple Third Ways' instead of referring to a single, consistent, well-elaborated one (White, 1998; Merkel, 2001).

How shall we interpret the existence of 'multiple Third Ways'? Is it due to the considerable differences between national traditions or is there another underlying factor? It seems like it is basically related to a new characteristic of contemporary social democracy: its depthless, weak ideological identity that links its fate more to the political context specific to each conjuncture (Moschonas, 2002, pp. 235-239). For this reason, with the lack of strong ideological attachments and programmatic commitments, the 'Third Way' politics has different faces in each political context.

Yet, despite the fact that centre-left politics present different characteristics in each national context, there has been a convergence between social democratic styles of different European centre-left political parties during the last two decades. Although its weak ideological identity did not allow social democracy to influence the value systems and attitudes of contemporary societies, it could create a convenient political atmosphere for the strengthening of transnational social democracy. For this reason, one of the future characteristics of a transnational social democracy could be based on the absence of strong attachments and commitments. Thus, as being more flexible, European social democrats had the chance to come together in the melting pot of a transnational federation, namely the Party of European Socialists.

\section{The Party of European Socialists}

The PES (the Confederation of Socialist Parties in the European Community - CSPEC till 1992) can be considered as the initial body of transnational social democracy in Europe, but the dominance of national governments on the EU governance hinders the development of a transnational political party. Social democratic politics at the PES level is about 
contending 'individual member parties' rather than pursuing a social democratic EU-oriented ideology. The PES is considered as a coordinating mechanism and discussion platform for Socialists and Social Democrats in the European institutions (Hix, 1995; Newman, 1996; and Ladrech, 2000, Ladrech, 2003, Lightfoot, 2005).

Although all European social democratic parties seem to support the idea of a regulated capitalism, there is no consistency among them. As the neoliberal orientation of the EU began to decline with the emphasis put on a European social model, the PES emerged as the transnational body of European social democracy to serve as an organ to determine a common agenda, especially on the issue of employment. The employment issue gradually became more and more important as the EU governance came to understand that the missing social side has been the main reason underlying the legitimacy crisis of the European integration (see PES, 1999a, 1999b and 1999c).

The main objective of the PES used to be reconstructing a full employment society throughout the 2000s. The PES stance on employment has been a compromise between economic liberalism and social regulation that perfectly fits into the logic of the Third Way. To achieve full employment they aimed to use macroeconomic policies, those create stability and are conducive to sustainable expansion, to make a social contract for solidarity, equal opportunities and justice, which gives to all citizens a stake in the development of the European economy, and to implement economic reforms which stimulate innovation and increase the potential for growth in the European economy (PES, 1998: 1). But the idea of increasing employability and labour market inclusion was blind to the concepts of class, exploitation and inequality.

The PES also presupposed a global role for the EU. For them "the EU must take the lead in the fight against poverty through more equal trade conditions, debt reduction and direct aid." They aim to "restrict speculative capital movements and examine the feasibility of fiscal means to achieve this" (PES, 1999b). However, the so-called 'Tobin Tax', which used to be considered as one of the most effective means to restrict speculative capital movements, was not supported by all the member parties of the PES. Even if it is possible to find some elements of an agenda proposal for global social democracy in some of the European social democratic and socialist parties, as in the case of French Socialist Party's (PS) or former German finance minister Oscar Lafontaine's attempts in the EU, the PES did not have a coherent stance on issues such as coordinated lowering of interest rates and financial transactions tax.

An analysis of the PES documents revealed that the main programmatic reference underlying the policy offers of the PES was the Third Way. In accordance with the Third Way politics, the PES called for an improvement in quality and capacity of education, training and skill development while regarding the option of working time reduction as an instrument for re-education. Some policy offers of the federation implied a reconstruction of the welfare state towards an employment friendly system (Levitas, 1998).

In the hands of the PES, social democracy is no longer an ideological programme that will pave the way for the democratic transformation of the society, but instead, a label that refers to a model of capitalist development. In effect, the PES lacks a stabilizing principle based on a strong organizational, social and programmatic anchorage. The existence of the PES is more political and practical and less ideological. Compared to any social democratic or socialist party, its programmatic references lack depth.

On the other hand, social democracy's presence at the supranational level should not merely be seen as an attempt to acquire benefits that social democratic parties are incapable of securing at the national level. Ladrech (2000) defined a successful transnational party "as an organizational nexus involved in the shaping of national party demands to fit the logic of the EU governance" (p. 90). This is a statement from the side of national parties that renders transnational level dependent on the national one.

As long as European social democrats do not change their view of the PES as a simple coordinating body that brings together the member parties, it is unlikely that transnational social democracy will evolve towards a consistent political force in the EU. In this context, the PES should aim to provoke party political competition within the EU. Unless it does not differentiate social democracy from other political currents in the EU system, it cannot become relevant in the eyes of the public. As each political group has to create its own adversaries, the PES, in the name of transnational European social democracy, needs to be clear about its own identity and its 'enemy'.

\section{Conclusion}

European social democracy needs to adopt an alternative approach to reformulate its traditional values in accordance with the imperatives of the global world. This approach should go beyond the nationalist paradigm of old social democracy and shall not view European integration simply as an opportunity for national governments to regain their powers. Social democracy has a great tradition of adjustment, in other words, adapting to the conditions of time and space. Today, contemporary social democracy must adapt itself to the new conditions of 'new times', but not merely 
swaying between neoliberalism and post-war social democracy. It has to search for a basis in its roots, reconsider its programmatic and ideological orientations in the light of these roots and look forward for the possibility of the revival of its 'core' principles under the new conditions that globalization, in general and the EU, in particular have brought about.

Socialism, the predecessor of social democracy has been an internationalist working class movement that aimed to emancipate humanity from the ills of capitalism. Social democracy adopted this emancipatory politics at the national level with a specific reference to the redistributive capacities of the nation-state. Eventually, social democratic parties transformed into pragmatic, reformist parties that aimed to gain the governmental power and thus, became dependent on the capacities of the nation-state. According to Sassoon (1996), "the close collaboration between the modern democratic nation-state and the parties of the Left has profoundly marked the experience of the last hundred years. These habits will not be easily discarded. Socialists, unavoidably, became "nationalist" (p. 771). This fact has undermined the internationalist aspect of European social democracy and triggered many of its contemporary problems. Social democracy today does not have the means and the will to contest the established power relations both at the national and transnational levels. And the Third Way lacked the spirit of resistance and aggressive mentality to handle the challenge of globalization.

Social democracy needs a new ideological project of transnational identity that would give it a hegemonic power at the ideological level. Such hegemony helped the post-war social democracy in the implementation of welfare state measures even when it was not in power. As long as capitalism continues to generate injustice and instability, movements seeking its reform will emerge to challenge it.

\section{References}

Callinicos, A. (2001). Against the Third Way: an anti-capitalist critique. Cambridge: Polity Press.

Clift, B. (2001). New Labour's Third Way and European Social Democracy. In: Ludlam, S., and Smith. M. (Eds.), New Labour in Government, (pp. 55-71). Basingstoke: Macmillan.

Gamble, A. and Wright, T. (Eds.), (1999). The New Social Democracy. Oxford: Blackwell.

Giddens, A. (1998). The Third Way: The Renewal of Social Democracy. Cambridge: Polity Press.

Merkel, W. (2001) The Third Ways of Social Democracy. In: Giddens, A. (Eds.), The Global Third Way Debate, (pp.50-73). Cambridge: Polity Press.

Gray, J. (1996). After Social Democracy. London: Demos.

Habermas, J. (1999). The European Nation-State and the Pressures of Globalization. New Left Review, No. 235, May-June, pp. $46-59$.

Habermas, J. (2001). Why Europe Needs a Constitution. New Left Review II, No. 11, September-October, pp. 5-26.

Hay, C. (1999). The Political Economy of the New Labour; Labouring under false preferences. Manchester: Manchester University Press.

Hix, S. (1995). A History of the PES, 1957-1994. Brussels: PES.

Ladrech, R. and Malière, P. (Eds.), (1999). Social Democratic Parties in the European Union. Basingstoke: Macmillan.

Ladrech, R. (2000). Social Democracy and the Challenge of European Union. London: Lynne Reinner.

Ladrech R. (2003). The Party of European Socialists: Networking Europe's Social Democrats. Journal of Policy History, vol. 15(1), pp. 113-129.

Levitas, R. (1998). The Inclusive Society? Social Exclusion and New Labour. Basingstoke: Macmillan.

Lightfoot, S. (2005). Europeanizing social democracy?: the rise of the Party of European Socialists. London: Routledge.

Martell, L. et al. (Eds.), (2001). Social Democracy: global and national perspectives. Basingstoke: Palgrave.

Moschonas, G. (2002). In the Name of Social Democracy; The Great Transformation: 1945 to the Present. London: Verso.

Newman, O. and de Zoysa, R. (2001). The promise of the third way: globalization and social justice. Basingstoke: Palgrave.

PES (1998). The New European Way - Economic Reform in the framework of EMU. Report by the PES EcoFin Group.

PES (1999a). A New Agenda for European Development Co-operation. Report by the PES Development Group.

PES (1999b). A European Employment Pact For A New European Way. Report from PES Party Leaders.

PES (1999c). Manifesto for the 1999 European Elections. Brussels: PES.

Pierson, C. (2001). Hard Choices: Social Democracy in the 21st century. Cambridge: Polity Press.

Sassoon, D. (1996). One Hundred Years of Socialism. London: Tauris.

Vandenbroucke, F. (1998). Globalisation, Inequality and Social Democracy. London: Institute for Public Policy Research.

White, S. (1998). Interpreting the 'Third Way': Not One Route, But Many. Renewal, Vol. 6, No. 2, pp. 17-30. 